\title{
Abnormal expression of TGF-beta type II receptor isoforms contributes to acute myeloid leukemia
}

\author{
Yong Wu ${ }^{1}$, Min Su${ }^{1}$, ShuX Zhang ${ }^{1}$, Yu Cheng ${ }^{1}$, Xiao Y. Liao ${ }^{1}$, Bao Y. Lin ${ }^{1}$, Yuan Z. \\ Chen ${ }^{1}$ \\ ${ }^{1}$ Fujian Institute of Hematology, Department of Hematology, Union Hospital, Fujian Medical University, Fuzhou, China \\ Correspondence to: Yuanzhong Chen, email: chenyz@mail.fjmu.edu.cn \\ Keywords: TGF- $\beta$, type II receptor, isoform, myeloid, leukemia
}

Received: April 14,2016 Accepted: November 30, 2016

Published: December 28, 2016

\section{ABSTRACT}

\begin{abstract}
Altered transforming growth factor-beta (TGF- $\beta$ ) signaling has been implicated in the pathogenesis of leukemia. Although TGF- $\beta$ type II receptor (T $\beta R I I)$ isoforms have been isolated from human leukemia cells, their expression patterns and functions of these variants are unclear. In this study, we determined that two TBRII isoforms (TRRII and TBRII-B) are abnormally expressed in leukemic cells, as compared to normal hematopoietic cells. TRRII-B, but not TBRII, was found to promote cell cycle arrest, apoptosis, and differentiation of leukemic cells. T $\beta$ RII-B also enhanced TGF- $\beta 1$ binding and downstream signaling and reduced tumorigenicity in vivo. By contrast, TRRII blocked all-trans retinoic acid-induced differentiation through inhibition of TRRII-B. Overall survival was significantly lower in acute myeloid leukemia (AML) patients with high compared to low TRRII expression. Thus, whereas TBRII-B is a potent inducer of cell cycle arrest, apoptosis, and differentiation, higher T $\beta R I I$ expression correlates with poor clinical prognosis in AML.
\end{abstract}

\section{INTRODUCTION}

Transforming growth factor-beta 1 (TGF- $\beta 1)$ is a potent inhibitor of hematopoietic cells. Autocrine- and paracrine-mediated binding of TGF- $\beta 1$ to cell surface receptors regulates hematopoietic cell proliferation, differentiation, and apoptosis [1, 2]. TGF- $\beta 1$ function is mediated by its interaction with transmembrane serine/ threonine kinase receptors. It forms a heteromeric complex comprised of TGF- $\beta$ receptor type I (T $\beta R I)$ and type II (T $\beta$ RII). TGF- $\beta 1$ stimulation leads to phosphorylation of the transcription factors Smad2 and/or Smad3, which form a complex with Smad4. This complex translocates to the nucleus where it modulates the transcription of target genes by directly binding to DNA or interacting with promoter-specific transcription factors [3-5].

Altered TGF- $\beta$ signaling has been observed in various human cancers [6-9]. However, the role of aberrant TGF- $\beta$ signaling in leukemogenesis has not been investigated. The potential role(s) of TGF- $\beta$ signaling in the pathogenesis of leukemia has attracted attention because TGF- $\beta$ negatively regulates hematopoiesis $[10,11]$. For example, in acute myeloid leukemia (AML), two distinct mutations in Smad4 (a missense mutation and a frameshift mutation) disrupt its ability to potentiate TGF- $\beta$ transcriptional activity [12]. We previously reported that TGF- $\beta 1$ expression was reduced in AML patients compared to healthy individuals. Interestingly, TGF- $\beta 1$ expression returned to approximately normal levels in leukemia patients who achieved complete remission, but decreased after recurrence [13]. Other studies have demonstrated reduced TGF- $\beta 1$ levels in several myeloid leukemia cell lines and in primary AML cells compared to normal cells. Ectopic expression of TGF- $\beta 1$ in HL60 cells (human promyelocytic leukemia cells) inhibited proliferation and induced apoptosis both in vitro and in vivo [14]. Loss of T $\beta R I$ and T $\beta$ RII expression has also been observed in patients with myeloid leukemia [15]. Collectively, the data suggest that TGF- $\beta$ signaling plays an important role in myeloid leukemogenesis.

An alternatively spliced variant of human T $\beta$ RII (TRRII-B), which contains an insertion of 26 amino acids in place of Val32 of TRRII, was described previously [16]. Several studies have confirmed that TRRII-B is a functional TGF- $\beta$ type II receptor that is expressed in a variety of cell lines [17-19]. We previously detected T $\beta$ RII-B in human leukemia cells [20]. However, the expression patterns and functions of T $\beta$ RII isoforms in leukemic cells have not yet been elucidated. 
In this study, we examined the expression profiles of T $\beta$ RII and T $\beta$ RII-B in AML cells by real-time reverse transcription PCR (RT-PCR). Our data indicate that T $\beta$ RII and T $\beta$ RII-B are differentially expressed in AML and normal hematopoietic cells. T $\beta$ RII-B is predominantly expressed in normal cells, while T $\beta$ RII is primarily expressed in AML cells. We investigated the functions of the isoforms by stably expressing either T $\beta$ RII or T $\beta$ RII-B in K562 (myeloid leukemia) and HL60 (promyelocytic) cells. These cell lines were selected because they displayed low endogenous T $\beta$ RII expression. We performed knockdown and rescue experiments in NB4 cells, which have high T $\beta$ RII expression. These experiments revealed more pronounced TGF- $\beta 1$-induced inhibition of proliferation and apoptosis in K562/T $\beta$ RII-B and HL60/T $\beta$ RII-B cells. Additionally, HL60/T $\beta$ RII-B cells were more sensitive to all-trans retinoic acid (ATRA)-induced differentiation and $\mathrm{As}_{2} \mathrm{O}_{3}$-induced apoptosis. T $\beta \mathrm{RII}$ inhibited ATRAinduced differentiation of NB4 cells by blocking T $\beta$ RII-B. Interestingly, TGF- $\beta 1$ had a higher affinity for T $\beta$ RII-B than T $\beta$ RII, and HL60/T $\beta$ RII-B cells exhibited reduced tumorigenicity in vivo. Thus, aberrant expression of T $\beta$ RII isoforms in myeloid leukemia cells is associated with abnormal proliferation and differentiation, and inhibition of apoptosis. Additionally, high T $\beta$ RII expression in leukemic cells is indicative of a poor prognosis in AML patients.

\section{RESULTS}

\section{Analysis of the expression of T $\beta$ RII and T $\beta$ RII-B in primary myeloid leukemia cells, cell lines, and normal bone marrow CD34+ cells}

We first investigated the expression of T $\beta$ RII isoforms in human leukemic cells using RT-PCR. Both T $\beta$ RII and T $\beta$ RII-B mRNA expression was detected in primary AML cells, normal bone marrow CD34+ cells, and four AML cell lines (U937, KG-1, NB4, and HEL). In contrast, both isoforms were expressed at low levels in K562 and HL60 cells. T $\beta$ RII was differentially expressed in leukemic cells and normal bone marrow cells. T $\beta$ RII was primarily expressed in AML cells while T $\beta$ RII-B was predominantly expressed in normal myeloid cells (Figure 1A-1B). T $\beta$ RII was expressed at lower levels in K562 and HL60 cells than in the other cell lines (NB4, U937, KG-1, and HEL) (Figure 1C). Based on these results, used K562 and HL60 cells for functional analyses of the two isoforms. We also performed knock-down and rescue experiments using NB4 cells, which have high $\mathrm{T} \beta \mathrm{RII}$ expression, in order to investigate how the expression of T $\beta$ RII impacted T $\beta$ RII-B function.

\section{T $\beta$ RII-B, but not T $\beta R I I$, induces cell proliferation inhibition, apoptosis, and differentiation}

To elucidate the functions of the two isoforms, we stably expressed either T $\beta$ RII or T $\beta$ RII-B in the
K562 and HL60 myeloid leukemia cell lines. Both cell lines have low endogenous T $\beta$ RII expression. These cell lines (referred to herein as K562/T $\beta$ RII, K562/ T $\beta$ RII-B, HL60/T $\beta R I I$, and HL60/T $\beta$ RII-B) were used to assess the impact on cell proliferation, apoptosis, and differentiation. T $\beta$ RII and T $\beta$ RII-B expression in these cells was confirmed using quantitative RT-PCR and Western blotting (Supplementary Tables 1 and 2, and Supplementary Figure 1A-1B). We performed MTT assays to evaluate the effects of TGF- $\beta 1$ on the proliferation of K562 and HL60 cells that expressed either T $\beta$ RII or T $\beta$ RII-B. The cells were incubated with different concentrations of TGF- $\beta 1$ for various times and the $\mathrm{IC}_{50}$ values calculated (Figure $2 \mathrm{~A}-2 \mathrm{~B}$ ). Treatment with a low concentration of TGF- $\beta 1(1 \mathrm{ng} / \mathrm{mL})$ inhibited the proliferation of K562/T $\beta$ RII-B and HL60/T $\beta$ RII-B cells, whereas K562/T $\beta$ RII and HL60/T $\beta$ RII cells were not affected. We next performed cell cycle analysis (i.e. DNA ploidy) using flow cytometry (Figure 2C-2D, Supplementary Tables 3 and 4). After incubation with $1 \mathrm{ng} / \mathrm{mL}$ TGF- $\beta 1$ for $24 \mathrm{~h}$ or $48 \mathrm{~h}$, HL60/T $\beta$ RII-B cells, but not HL60/T $\beta$ RII cells, were arrested in the G1 phase. The same effect was observed in K562/T $\beta$ RII-B and K562/T $\beta$ RII cells. These data suggested that T $\beta$ RII did not have the capacity to induce cell cycle arrest in AML cells.

To determine whether TGF- $\beta 1$ could induce apoptosis in K562 and HL60 cells that expressed different T $\beta$ RII isoforms, we measured apoptosis using annexin V-FITC/propidium iodide (PI) staining and flow cytometry (Figure 2E-2F). Apoptosis was observed in $16.49 \%$ and $18.26 \%$ of K562/T $\beta$ RII-B and HL60/ T $\beta$ RII-B cells, respectively. Of the K562/T $\beta$ RII and HL60/T $\beta$ RII cells, 5.93\% and $11.44 \%$, respectively, were apoptotic. To study the effect of T $\beta$ RII expression on $\mathrm{As}_{2} \mathrm{O}_{3}$-induced apoptosis, HL60 cells that expressed the different T $\beta$ RII isoforms were incubated with various concentrations of $\mathrm{As}_{2} \mathrm{O}_{3}$ for $24 \mathrm{~h}$. Cells that were doublestained with annexin V-FITC/PI were then detected using flow cytometry. A low concentration of $\mathrm{As}_{2} \mathrm{O}_{3}(4 \mu \mathrm{M})$ triggered apoptosis in HL60/T $\beta$ RII-B cells but failed to induce apoptosis in HL60/T $\beta$ RII and parental HL60 cells (Figure 2G). Apoptosis was also observed in HL60/T $\beta$ RII and parental HL60 cells after treatment with higher $\mathrm{As}_{2} \mathrm{O}_{3}$ concentrations $(8 \mu \mathrm{M}$ and $10 \mu \mathrm{M}))$, but to a lesser extent than in HL60/T $\beta$ RII-B cells. These data suggest that T $\beta$ RII did not have the capacity to induce AML cell apoptosis.

We next investigated the response of HL60 cells that expressed different T $\beta$ RII isoforms to ATRA-induced differentiation.HL60/T $\beta$ RII and HL60/T $\beta$ RII-B cells were first incubated with different concentrations of ATRA for $96 \mathrm{~h}$. The expression of CD11b on the cell surface was then detected by flow cytometry. We found that $0.1-1.0$ $\mu \mathrm{M}$ ATRA induced differentiation of HL60/T $\beta$ RII-B cells but not HL60/T $\beta$ RII or parental HL60 cells (Figure $2 \mathrm{H}$ ). These data suggested that unlikeT $\beta$ RII-B, T $\beta$ RII lacked the capacity to inhibit proliferation, apoptosis, and 
differentiation in vitro. To investigate the ability of HL60 cells expressing different T $\beta$ RII isoforms to proliferate in vivo, we inoculated the cells into nude mice and analyzed tumorigenesis. HL60/T $\beta$ RII-B cells exhibited weak tumorigenicity compared to HL60/T $\beta$ RII cells. Moreover, the tumor volumes in the HL60/T $\beta$ RII-B group were significantly lower than in the HL60/T $\beta$ RII and HL60/ NEO group 22 days after inoculation $(\mathrm{P}<0.05)$ (Figure 3$)$.

\section{T $\beta$ RII inhibits ATRA-induced differentiation of NB4 cells by blocking T $\beta$ RII-B}

To investigate how T $\beta$ RII expression affected T $\beta$ RII-B function, NB4 cells were stably infected with lentiviral vectors expressing T $\beta$ RII siRNA and T $\beta$ RII splice variants $(\mathrm{Mu})$. The splice variants $(\mathrm{Mu})$ contained synonymous mutations located in the sequences targeted by T $\beta$ RII siRNA (Supplementary Figure 2). Therefore,
T $\beta$ RII siRNA could silence the expression of endogenous T $\beta$ RII but not the expression of either T $\beta$ RII splice variant (Mu). Coinfection of NB4 cells with lentiviral vectors expressing both T $\beta$ RII splice variants $(\mathrm{Mu})$ and T $\beta$ RII siRNA resulted in stable expression of only the T $\beta$ RII splice variants $(\mathrm{Mu})$ and not endogenous T $\beta$ RII. These cell lines are referred to herein as NB4/T $\beta R I I$ and NB4/ T $\beta$ RII-B.

NB4 cells were infected at a multiplicity of infection (MOI) of 20 for $96 \mathrm{~h}$. The cells were then collected and the expression of T $\beta$ RII splice variant mRNA analyzed in each group. We determined that both T $\beta$ RII splice variants in the T $\beta$ RII siRNA group were downregulated by $81 \%$ relative to cells infected with the negative control vector or the uninfected control cells. Real-time PCR analysis confirmed that the T $\beta$ RII splice variants were stably expressed in the appropriate cell lines (Supplementary Figure 3). We next investigated the effects of ATRA on
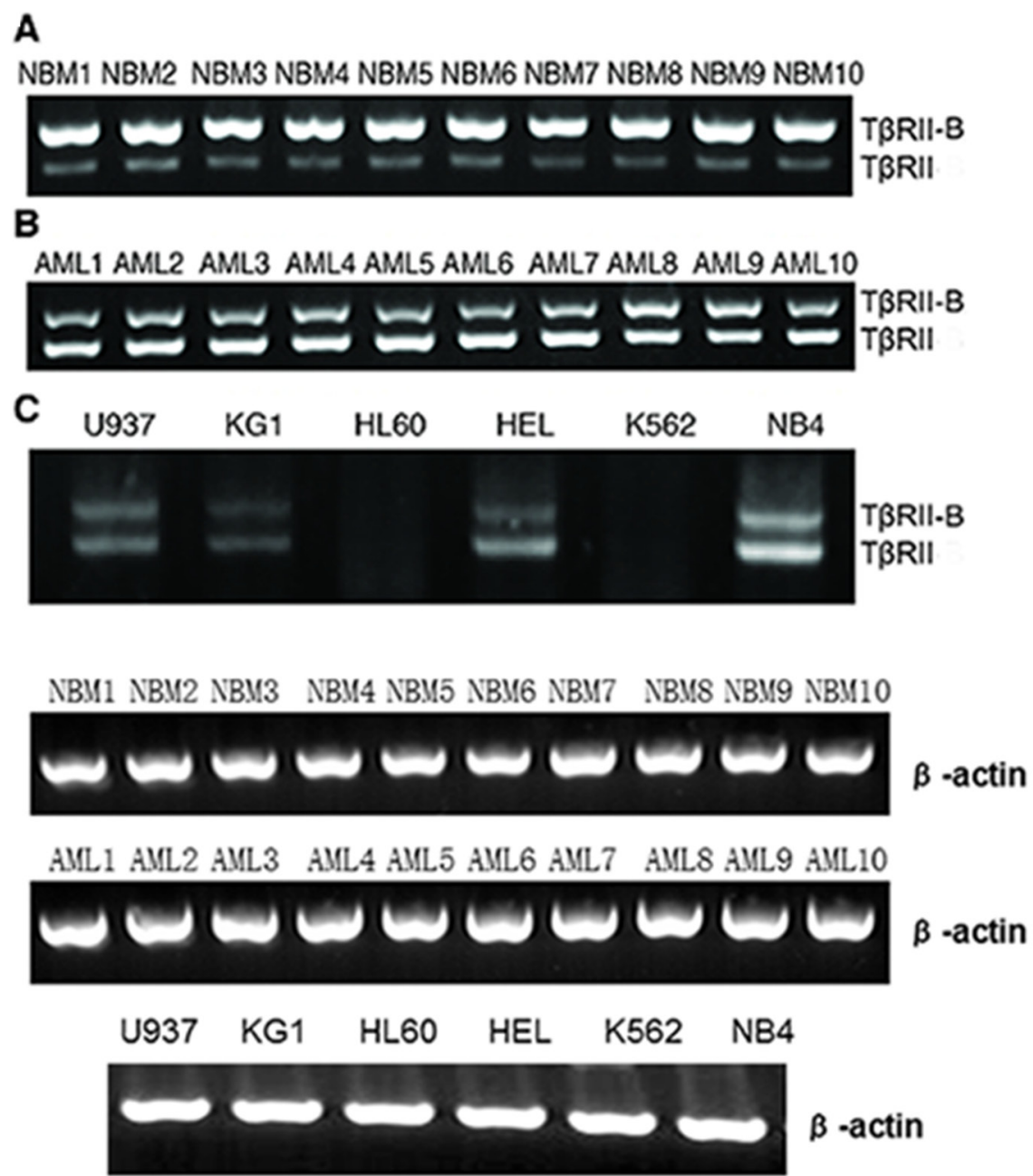

Figure 1: T $\beta$ RII and T $\beta$ RII-B expression in primary myeloid leukemia cells, cell lines, and normal bone marrow CD34+ cells. T $\beta$ RII and T $\beta$ RII-B mRNA was detected in all primary AML cells, normal bone marrow CD34+ cells, and four AML cell lines, with the exception of K562 and HL60 cells (both T $\beta$ RII isoforms were expressed at low levels). The leukemic cells and normal bone marrow cells differentially expressed T $\beta$ RII. T $\beta$ RII was mainly expressed in AML cells, whereas T $\beta$ RII-B was mainly expressed in normal myeloid cells. A. NBM indicates normal bone marrow CD34+ cells. B. AML indicates bone marrow mononuclear cells with AML. C. T $\beta$ RII was expressed at lower levels in K562 and HL60 cells than in other cell lines. 
the differentiation of these lentiviral-infected NB4 cells. NB4 cells from each group were infected with lentiviral vectors for $96 \mathrm{~h}$ and then incubated with $0.1 \mu \mathrm{M}$ ATRA for an additional $96 \mathrm{~h}$. Finally, NB4 cell differentiation was analyzed by flow cytometry. We observed a higher number of differentiated cells in the NB4/T $\beta$ RII-B group compared to the NB4/T $\beta$ RII and negative control groups $(\mathrm{P}<0.05)$. No ATRA-induced differentiation was observed in the NB4/T $\beta$ RII group compared to the negative control group $(\mathrm{P}>0.05)$ (Figure 4$)$. These data showed that ATRA-induced differentiation of NB4/T $\beta$ RII-B cells was enhanced by T $\beta$ RII knock-down. Thus, T $\beta$ RII perturbs ATRA-induced NB4 cell differentiation by inhibiting T $\beta$ RII-B.

\section{T $\beta$ RII lacks the ability to induce phosphorylation of TGF- $\beta 1 /$ Smad pathway members and the expression of downstream target proteins}

To study the molecular mechanisms underlying the functional differences in TGF- $\beta$ signaling between the two different isoforms, we analyzed the effects of TGF- $\beta 1$ on the phosphorylation of TGF- $\beta 1 /$ Smad pathway members in HL60 cells that stably expressed the different T $\beta$ RII isoforms. After incubation with $1 \mathrm{ng} / \mathrm{mL}$ TGF- $\beta 1$ for $0.5 \mathrm{~h}$ or $2 \mathrm{~h}$, phosphorylation of TGF- $\beta / \mathrm{Smad}$ signaling proteins was detected using an immunoassay consisting of 176 different antibodies (of which 74 antibodies targeted
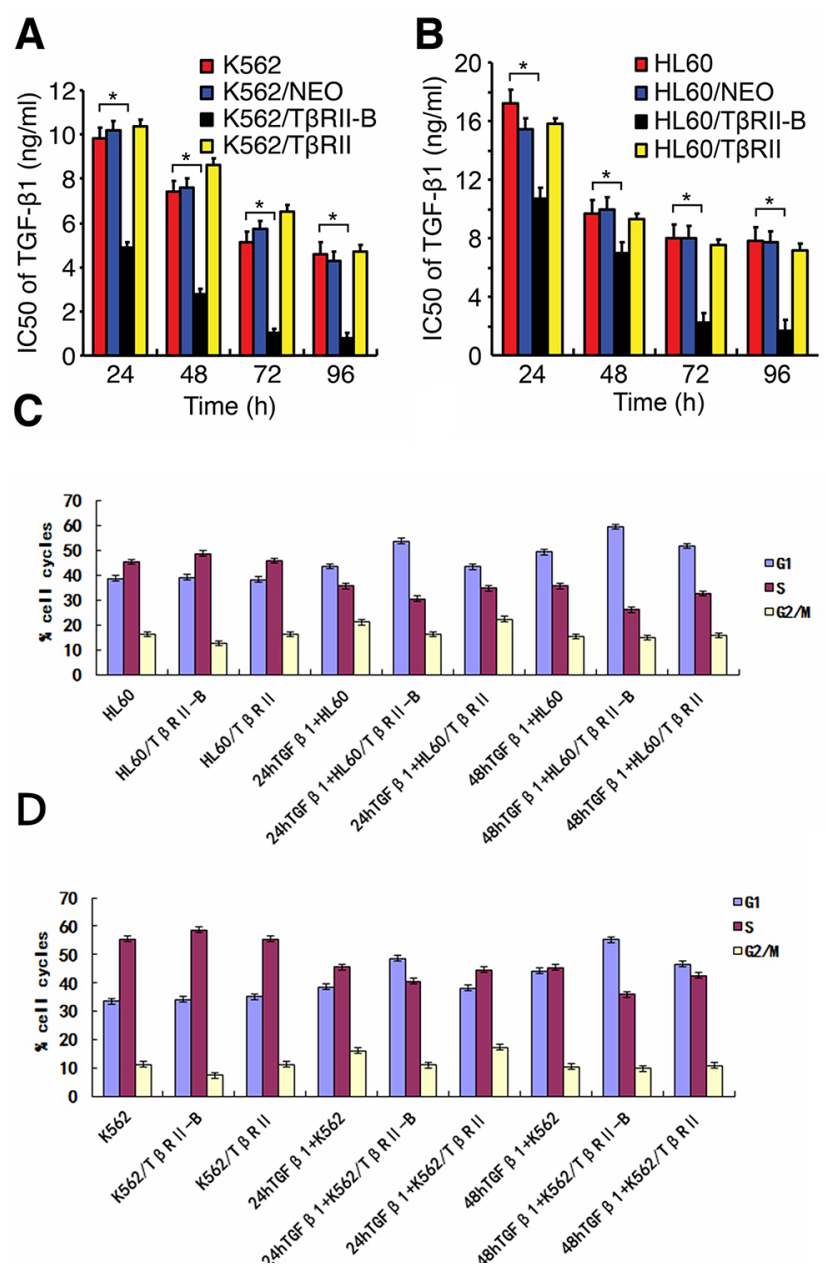

E
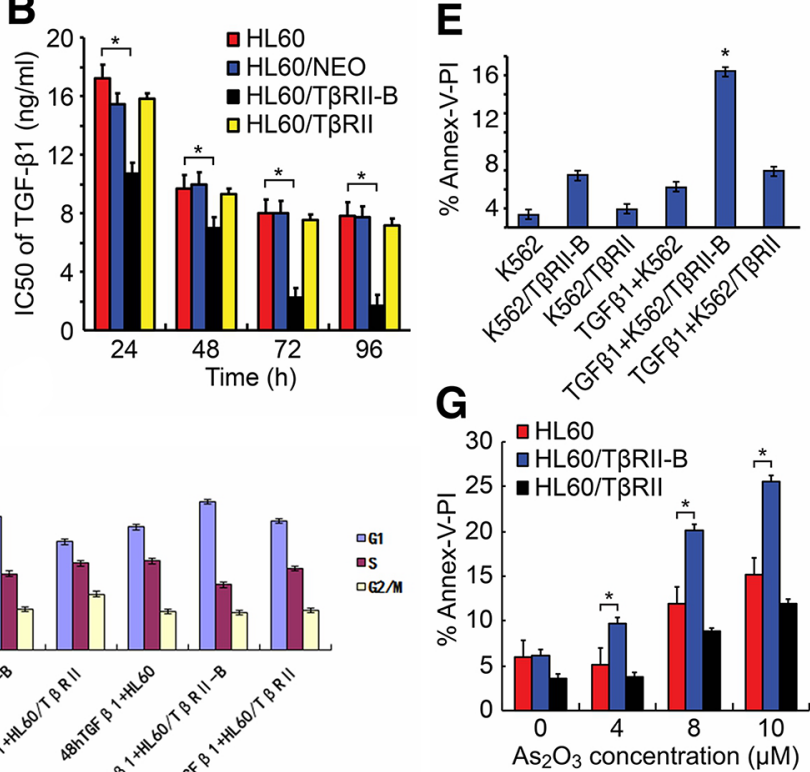

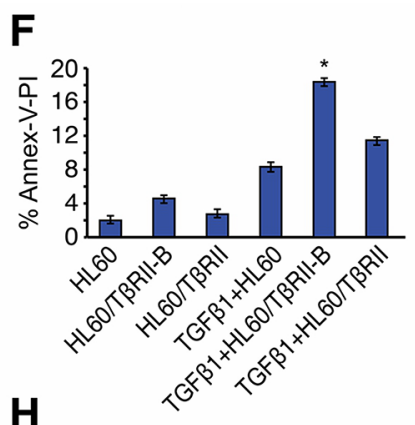

H

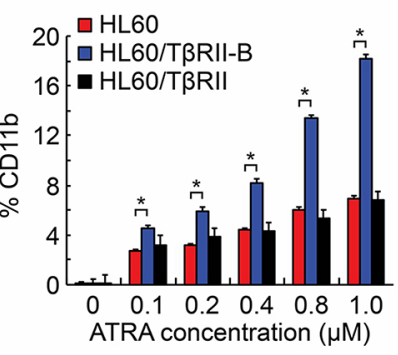

Figure 2: TßRII lacks the ability to induce cell proliferation inhibition, apoptosis, and differentiation. A. and B. MTT assays were performed in triplicated and $\mathrm{IC}_{50}$ values for TGF- $\beta 1$ calculated in K562 and HL60 cells that expressed either T $\beta$ RII or T $\beta$ RII-B. C. and D. Cell cycle analysis of K562 and HL60 cells expressing either T $\beta$ RII or T $\beta$ RII-B $24 \mathrm{~h}$ and $48 \mathrm{~h}$ after treatment with TGF- $\beta 1$ (1 ng/ $\mathrm{mL}$ ). The flow cytometry data are expressed as percentages of the G1, S, and G2/M phases. The data are representative of three independent experiments. E. and F. FACS analysis of apoptosis using annexin V-FITC/PI staining in TGF- $\beta 1$-treated (1 ng/mL) K562 and HL60 cells that stably expressed either T $\beta$ RII or T $\beta$ RII-B. The data are expressed as percentages of cells in early and late apoptosis. The data are representative of three independent experiments. G. Annexin V-FITC/PI staining for apoptosis induced by different concentrations of $\mathrm{As}_{2} \mathrm{O}_{3}$ in HL60 cells that expressed either T $\beta$ RII or T $\beta$ RII-B. The data are representative of three independent experiments. H. FACS analysis of ATRA-induced CD11b expression in HL60 cells that stably expressed the different T $\beta$ RII isoforms. The FACS data are expressed as percentages of CD11b, and the data are representative of three independent experiments. The data are expressed as the mean $\pm \mathrm{SEM}$. $* * \mathrm{P}$ $<0.01, * \mathrm{P}<0.05$, two-tailed Student's $t$-test. 
specific phosphorylation sites). The effects of TGF- $\beta 1$ on the phosphorylation status of eight specific phosphorylation sites in six proteins known to be involved in TGF- $\beta 1 /$ Smad signaling were investigated in HL60/T $\beta$ RII or HL60/T $\beta$ RII-B cells (Figure 5A and Supplementary Table 5). Phosphorylation of TGF- $\beta 1 / \mathrm{Smad}$ pathway members was significantly increased in HL60/T $\beta$ RII-B cells compared to HL60/T $\beta$ RII cells (Figure 5A1-2). The phosphorylation status of TGF- $\beta /$ Smad signaling proteins was confirmed by Western blotting (Supplementary Figure 4). Western blotting was also used to measure the levels of downstream targets of TGF- $\beta$ signaling in HL60 cells that stably expressed the different T $\beta$ RII isoforms. Treatment with $1 \mathrm{ng} / \mathrm{mL}$ TGF- $\beta 1$ for $6 \mathrm{~h}$ or $12 \mathrm{~h}$ resulted in an increase in $\mathrm{p} 21^{\mathrm{CIP} / \mathrm{WAF} 1}$. To a greater extent in HL60/ T $\beta$ RII-B cells than in HL60/T $\beta$ RII cells. In contrast, the levels of c-Myc levels significantly decreased, to a greater extent in HL60/T $\beta$ RII-B cells than in HL60/T $\beta$ RII cells. (Figure 5B).

To assess the effects of TGF- $\beta 1$ on genes involved in cell cycle control, apoptosis, and differentiation, we measured the mRNA levels of Bcl-2, c-Myc, hTERT, p21, IL-3, TNF $\alpha$, G-CSFR, and GM-CSFR $\alpha$ in HL60 cells that stably expressed the isoforms using quantitative RT-
PCR (Figure 5C). Treatment of HL60/T $\beta$ RII-B cells with TGF- $\beta 1$ resulted in a decrease in Bcl-2, c-Myc, hTERT, IL-3, and G-CSFR mRNA. However, an increase in p21 and TNF $\alpha$ mRNA levels was observed. No significant changes were observed in HL60/T $\beta$ RII cells.

\section{TGF- $\beta 1$ has a higher affinity for T $\beta R I I-B$ than for T $\beta R I I$}

To study the binding affinity of TGF- $\beta 1$ for T $\beta$ RII and T $\beta$ RII-B, different concentrations of $\left[{ }^{125} \mathrm{I}\right] \mathrm{TGF}-\beta 1$ were incubated with K562/T $\beta$ RII, K562/T $\beta$ RII-B, or control K562 cells. These results indicated that $40-80$ $\mathrm{pmol} / \mathrm{L}(1-2 \mathrm{ng} / \mathrm{mL}) \mathrm{TGF}-\beta 1$ bound more strongly to K562/T $\beta R I I-B$ cells than to K562/T $\beta$ RII cells (Figure 6).

\section{Higher T $\beta$ RII expression is correlated with a poor clinical prognosis in AML patients}

We next investigated whether the expression of T $\beta$ RII isoforms was associated with AML patient prognosis. We analyzed T $\beta$ RII and T $\beta$ RII-B expression in 138 AML patients using quantitative RT-PCR. Of the 60 AML patients with high T $\beta$ RII expression, $60 \%$ had

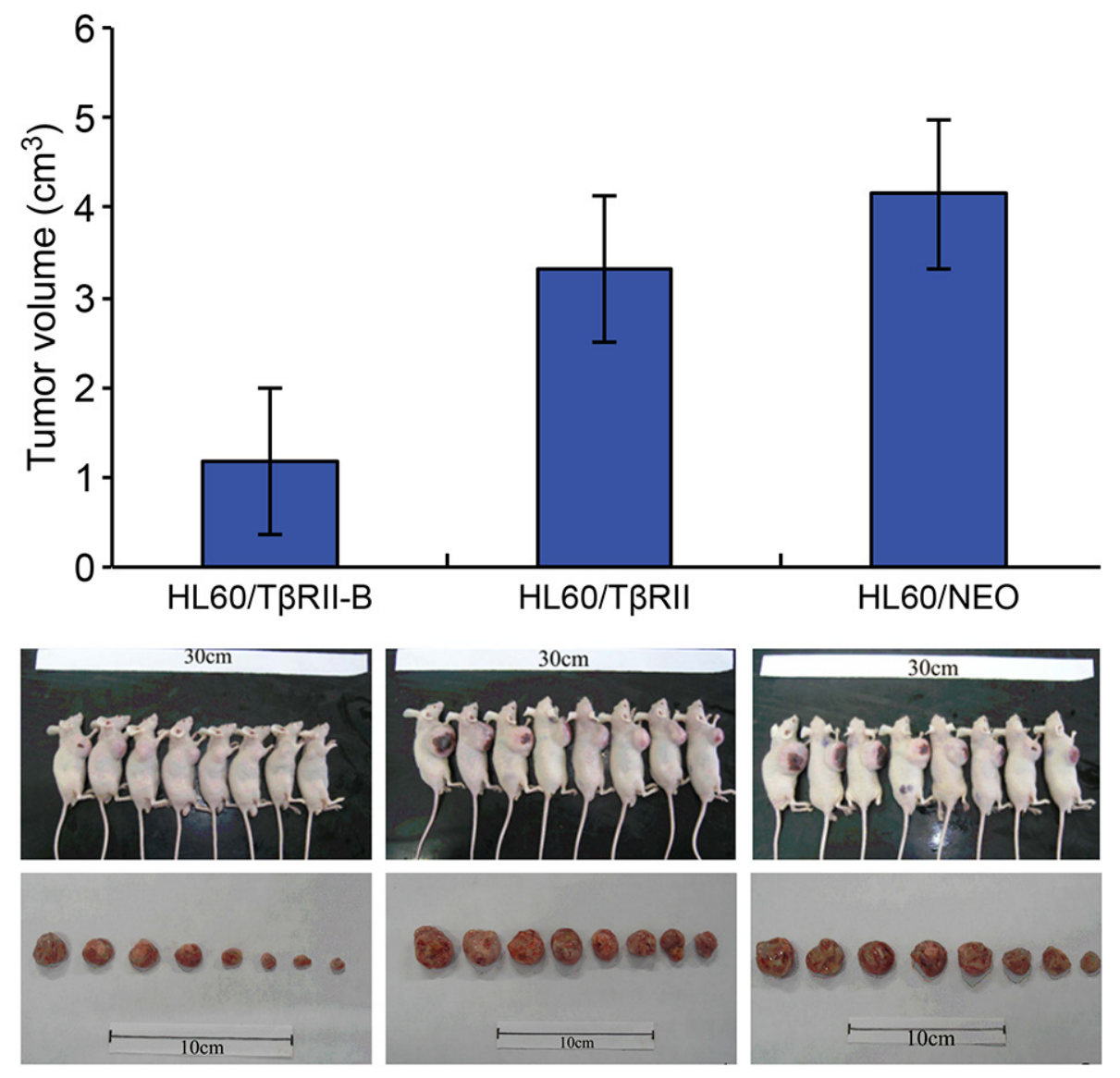

Figure 3: Growth of HL60/TßRII and HL60/T $\beta$ RII-B cells in BALB/c nude mice 22 days post-inoculation. The data are representative of two individual experiments. Each group contained eight mice. Representative images are shown. The data are expressed as the mean \pm SEM. $* * \mathrm{P}<0.01, * \mathrm{P}<0.05$, two-tailed Student's $t$-test. 
high leukemic cell counts. Of the 78 patients with low T $\beta$ RII expression, only $35.9 \%$ had high leukemic cell counts. Following treatment with two standard courses of chemotherapy, complete remission was observed in $40 \%$ of the AML patients who had high T $\beta$ RII expression, which was a significantly smaller fraction than the fraction of patients with low T $\beta$ RII expression who achieved remission (69.2\%) (Table 1). Additionally, the overall survival rate of patients with high T $\beta$ RII expression was significantly lower than that of patients with low T $\beta$ RII expression (34.3\% vs. 61.8\%, $\mathrm{P}=0.005$ ) (Figure 7). These data indicated T $\beta$ RII expression was significantly associated with patient prognosis. The characteristics of the AML patients (including genotype, gender, age, AML type, or karyotype) with high T $\beta$ RII expression did not significantly differ from those of patients with low T $\beta$ RII expression (Supplementary Table 6). In addition, the overall survival rates of patients with high T $\beta$ RII-B expression did not significantly differ from those of patients with low T $\beta$ RII-B expression (45.5\% vs. 50\%, $\mathrm{P}>0.05)$. Finally, no significant differences in leukemic cell counts, complete remission, genotype, gender, age, AML type, or karyotype were observed between AML patients with high T $\beta$ RII-B expression and patients with low T $\beta$ RII-B expression.

\section{DISCUSSION}

Our data have revealed that T $\beta$ RII and T $\beta$ RII-B mRNA are abnormally expressed in AML cells and normal bone marrow CD34+ cells. T $\beta$ RII was predominantly expressed in AML cells whereas T $\beta$ RII-B was predominantly expressed in normal bone marrow CD34+ cells. Higher levels of T $\beta$ RII and T $\beta$ RII-B mRNA were also detected in U937, KG-1, HEL, and NB4 cells relative to K562 and HL60 cells. T $\beta$ RII mRNA was also higher than T $\beta$ RII-B in U937, KG-1, HEL, and NB4 cells. We transfected T $\beta$ RII and T $\beta$ RII-B splice variants into K562 and HL60 cells, which have relatively low T $\beta R I I$ expression, and generated the following cell lines: K562/ T $\beta$ RII, K562/T $\beta$ RII-B, HL60/T $\beta R I I$, and HL60/T $\beta$ RII-B. Our data suggest that K562/T $\beta$ RII-B and HL60/T $\beta$ RII-B cells are more sensitive to TGF- $\beta 1$-induced growth inhibition and apoptosis than K562/T $\beta$ RII and HL60/ T $\beta$ RII cells.

We previously reported that ectopic expression of TGF- $\beta 1$ in HL60, which lack endogenous TGF- $\beta 1$ expression, inhibited cell proliferation and triggered apoptosis through downregulation of Bcl-2, c-Myc, and hTERT [14]. Here, we demonstrated that treatment with exogenous TGF- $\beta 1$ downregulated Bcl-2, c-Myc, and hTERT mRNA expression to a greater extent in HL60/T $\beta$ RII-B cells than in HL60/T $\beta$ RII cells. As a cell cycle inhibitor, TGF- $\beta 1$ not only suppresses the transcription of the Bcl-2, $-M y c$, and $h T E R T$ genes, but also activates expression of the cell cycle inhibitor $p 21^{C I P / W A F 1}$. We found that treatment with exogenous TGF- $\beta 1$ reduced c-Myc protein expression and increased p21 $1^{\mathrm{CIP} / \mathrm{WAF} 1}$ protein levels to a greater extent in HL60/T $\beta$ RII-B cells than in HL60/T $\beta$ RII cells. TGF- $\beta 1$ is known to regulate target gene expression through phosphorylation of R-Smad. We found that TGF- $\beta 1$ led to increased R-Smad phosphorylation as well as phosphorylation of downstream targets including PKC, AKT, and SAPK/JNK in HL60/T $\beta$ RII-B cells compared to HL60/T $\beta$ RII cells.

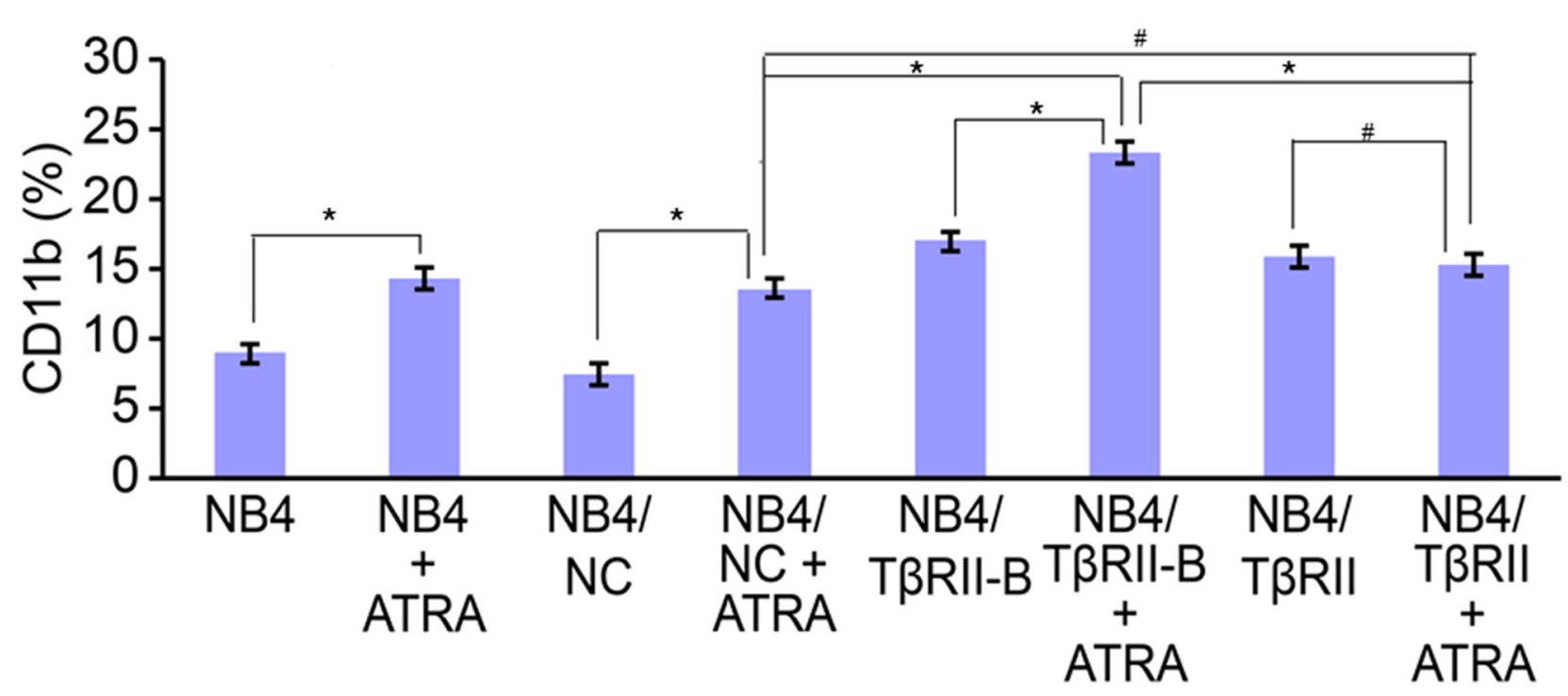

Figure 4: T $\beta$ RII perturbs ATRA-induced differentiation of NB4 cells through blocking T $\boldsymbol{\beta}$ III-B. NB4 cells were infected with lentiviral vector for $96 \mathrm{~h}$ and then incubated with $0.1 \mu \mathrm{M}$ ATRA for an additional $96 \mathrm{~h}$. FACS analysis of ATRA-induced $(0.1 \mu \mathrm{M})$ CD11b expression in NB4 cells after knock-down of endogenous T $\beta$ RII and expression of the different T $\beta$ RII isoforms. FACS data are expressed as percentages of $\mathrm{CD} 11 \mathrm{~b}$ expression, and the data are representative of three independent experiments. The data are expressed as the mean \pm SEM. $\# \mathrm{P}>0.05, * \mathrm{P}<0.05$, two-tailed Student's $t$-test. 
Previous studies have suggested that TGF- $\beta 1$ alone cannot induce significant HL60 cell differentiation. However, TGF- $\beta 1$ in combination with low-dose ATRA (lower than therapeutic levels) could induce differentiation of HL60 cells [21]. We previously reported that ATRAinduced HL60 cell differentiation was associated with upregulation of endogenous TGF- $\beta 1$, which suggested a synergistic relationship between the two reagents [22]. Combined TGF- $\beta 1$ and vitamin D3 also had a stronger effect on differentiation in HL60 cells than either reagent alone. The combined effect on differentiation was primarily mediated by $S m a d 2 / 3$ phosphorylation and nuclear translocation [23]. Here, we found that HL60/TßRII-B cells were more sensitive to ATRA-induced differentiation than HL60/T $\beta R I I$ cells. These results suggested that ATRA-induced upregulation of endogenous TGF- $\beta 1$ acted on TRRII signaling to induce cell differentiation. Other studies have suggested that $\operatorname{Smad} 2 / 3$ phosphorylation could be used as a sensor of TGF- $\beta 1$ - and ATRA-induced differentiation of HL60 cells into monocytes or myeloid cells. In our study, TGF- $\beta 1$ alone induced differentiation of HL60 cells into monocytes. This effect was accompanied by rapid phosphorylation and nuclear translocation of Smad2/3. In contrast, ATRA induced the differentiation of HL60 cells into myeloid cells, but this process occurred without Smad2/3 phosphorylation and nuclear translocation. Treatment of HL60 cells with TGF- $\beta 1$ plus ATRA resulted in differentiation of HL60 cells into both myeloid and monocyte cells [24]. The mRNA and protein levels of several TGF- $\beta 1$ signaling pathway components including TGF- $\beta 1$, T $\beta$ RI, T $\beta$ RII, Smad2, Smad4, and Smad7 were previously shown to increase in response
A-1

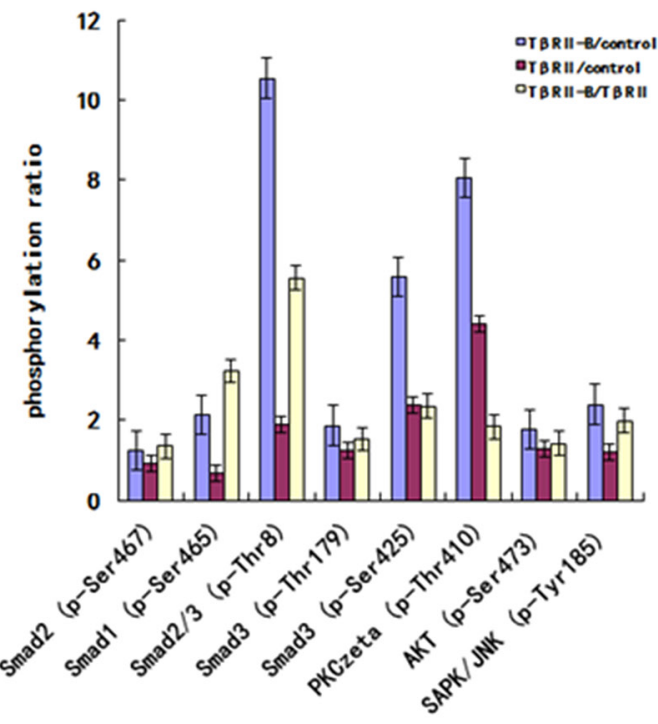

A-2

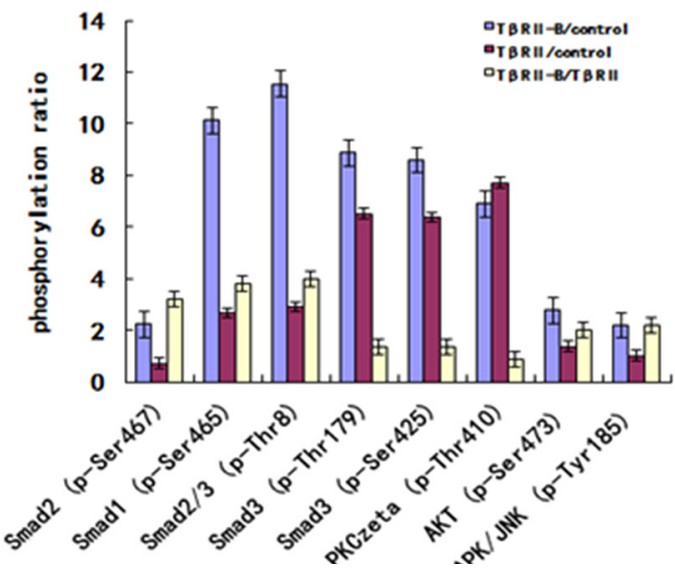

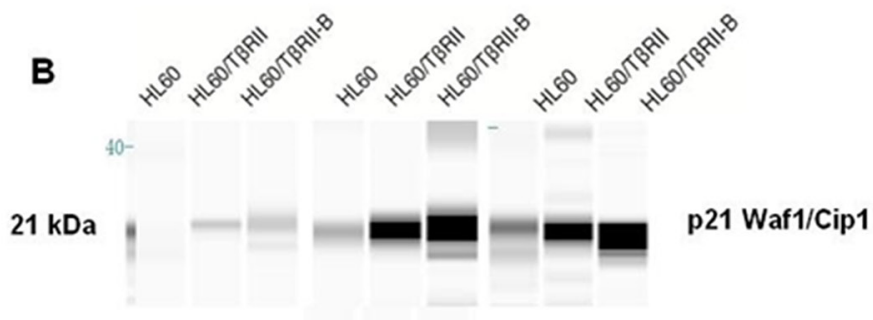

$72 \mathrm{kDa}$

66-

$49 \mathrm{kDa}$

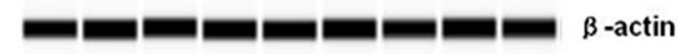

$40-$

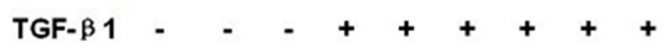

Oh

$6 \mathrm{~h}$

$12 \mathrm{~h}$

C

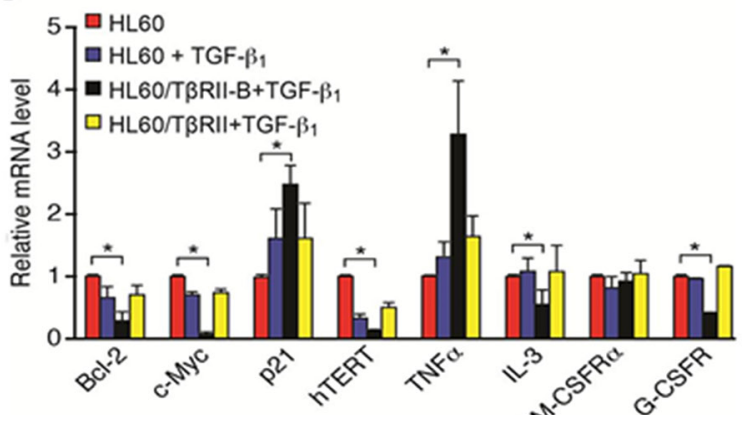

Figure 5: T $\beta R I I$ is deficient in inducing phosphorylation of TGF- $\beta 1 /$ Smad pathway members and the expression of downstream target proteins. A1-2. Phosphorylation of TGF- $\beta 1 /$ Smad pathway members increased significantly in HL60/T $\beta$ RII-B cells compared to HL60/T $\beta$ RII cells after incubation with $1 \mathrm{ng} / \mathrm{mL}$ TGF- $\beta 1$ for $0.5 \mathrm{~h}$ or $2 \mathrm{~h}$. B. Western blot analysis of c-Myc and p21CIP/ WAF1 expression in TGF- $\beta 1$-treated ( $1 \mathrm{ng} / \mathrm{mL}$ ) HL60 cells that stably expressed different T $\beta R$ II isoforms. Untreated HL60 cells served as a control. The data are representative of two independent experiments. C. Real-time PCR analysis of TGF- $\beta 1$ targets in HL60 cells expressing either T $\beta$ RII or T $\beta$ RII-B. Untreated HL60 cells served as a control. The experiment was performed in triplicate. The data are expressed as the mean \pm SEM. $* \mathrm{P}<0.05$, two-tailed Student's $t$-test. 
to ATRA-induced NB4 cell differentiation. These results indicate that upregulation of TGF- $\beta 1$ signaling pathway components plays an important role in ATRA-induced differentiation of NB4 cells.

We performed knock-down and rescue experiments in NB4 cells, which express high levels of endogenous T $\beta$ RII, to investigate how T $\beta$ RII expression impacted T $\beta$ RII-B function. We determined that there was more ATRA-induced differentiation in NB4/T $\beta$ RII-B cells compared to NB4/T $\beta$ RII and negative control cells. In contrast, no effects were observed in NB4/T $\beta$ RII cells compared to the negative controls. These data indicated that ATRA-induced differentiation of NB4/T $\beta$ RII-B cells was enhanced by T $\beta$ RII knock-down. Thus, T $\beta$ RII perturbs ATRA-induced differentiation of NB4 cells through inhibition of T $\beta$ RII-B.

We previously reported that $\mathrm{As}_{2} \mathrm{O}_{3}$ induced apoptosis in HL60 cells through upregulation of endogenous TGF- $\beta 1$ and downregulation of Bcl-2. TGF- $\beta 1$ antisense oligonucleotides inhibited $\mathrm{As}_{2} \mathrm{O}_{3}$-induced apoptosis and restored $\mathrm{Bcl}-2 \mathrm{mRNA}$ and protein to pre-treatment levels, suggesting an important role for endogenous TGF- $\beta 1$ in $\mathrm{As}_{2} \mathrm{O}_{3}$-induced HL60 cell apoptosis through downregulation of Bcl-2 [25]. Previous studies have also indicated that $\mathrm{As}_{2} \mathrm{O}_{3}$ and TGF- $\beta 1$ exert a synergistic effect on apoptosis compared to either $\mathrm{As}_{2} \mathrm{O}_{3}$ or TGF- $\beta 1$ treatment alone. Both $\mathrm{As}_{2} \mathrm{O}_{3}$ and TGF- $\beta 1$ downregulate $\mathrm{Bcl}-2$, suggesting that $\mathrm{Bcl}-2$ is the common effector shared by the two apoptotic pathways [26]. TGF- $\beta 1$ exerts this effect through its receptors. We found that HL60/T $\beta$ RII-B cells were more sensitive to TGF- $\beta 1$ - or $\mathrm{As}_{2} \mathrm{O}_{3}$-induced apoptosis than HL60/T $\beta$ RII cells.

In a physiological environment, hematopoietic stem cell proliferation, differentiation, and apoptosis are regulated by two types of cytokines: positive regulators (e.g. IL-1, IL-3, IL-6, G-CSF, GM-CSF, SCF, and TPO) and negative regulators (e.g. TGF- $\beta 1, \mathrm{TNF} \alpha$, and IFN $\gamma$ ). These cytokines regulate blood cell proliferation, differentiation, and apoptosis in either an autocrine or paracrine manner. TGF- $\beta 1$ downregulates the expression of the positive regulators to promote hematopoietic cell proliferation [27]. We previously found that TGF- $\beta 1$ could decrease IL-3, GM-CSFR, IL-6, and IL-6R expression in leukemic cells [13], and we demonstrated that TGF- $\beta 1$ increased TNF $\alpha$ mRNA expression and reduced IL-3 and G-CSFR mRNA expression in HL60/T $\beta$ RII-B but not in HL60/T $\beta$ RII cells. These findings suggest that leukemic cells expressing different T $\beta$ RII isoforms may alter the effects of TGF- $\beta 1$ on cytokines and cytokine receptors.

The structures of ternary complexes consisting of TGF- $\beta$ type I and type II receptors and TGF- $\beta 1$ have been solved. A comparison of the structure of the TGF- $\beta 1: T \beta R I I: T \beta R I$ ternary complex with the TGF- $\beta 3$ ternary complex revealed a common ligand recognition mode among receptors in the TGF- $\beta$ cytokine family [28]. Groppe et al. [29] showed that TGF- $\beta 3$ bound to the extracellular region of T $\beta \mathrm{RI}$, and that the N-terminus of T $\beta$ RII interacted with the

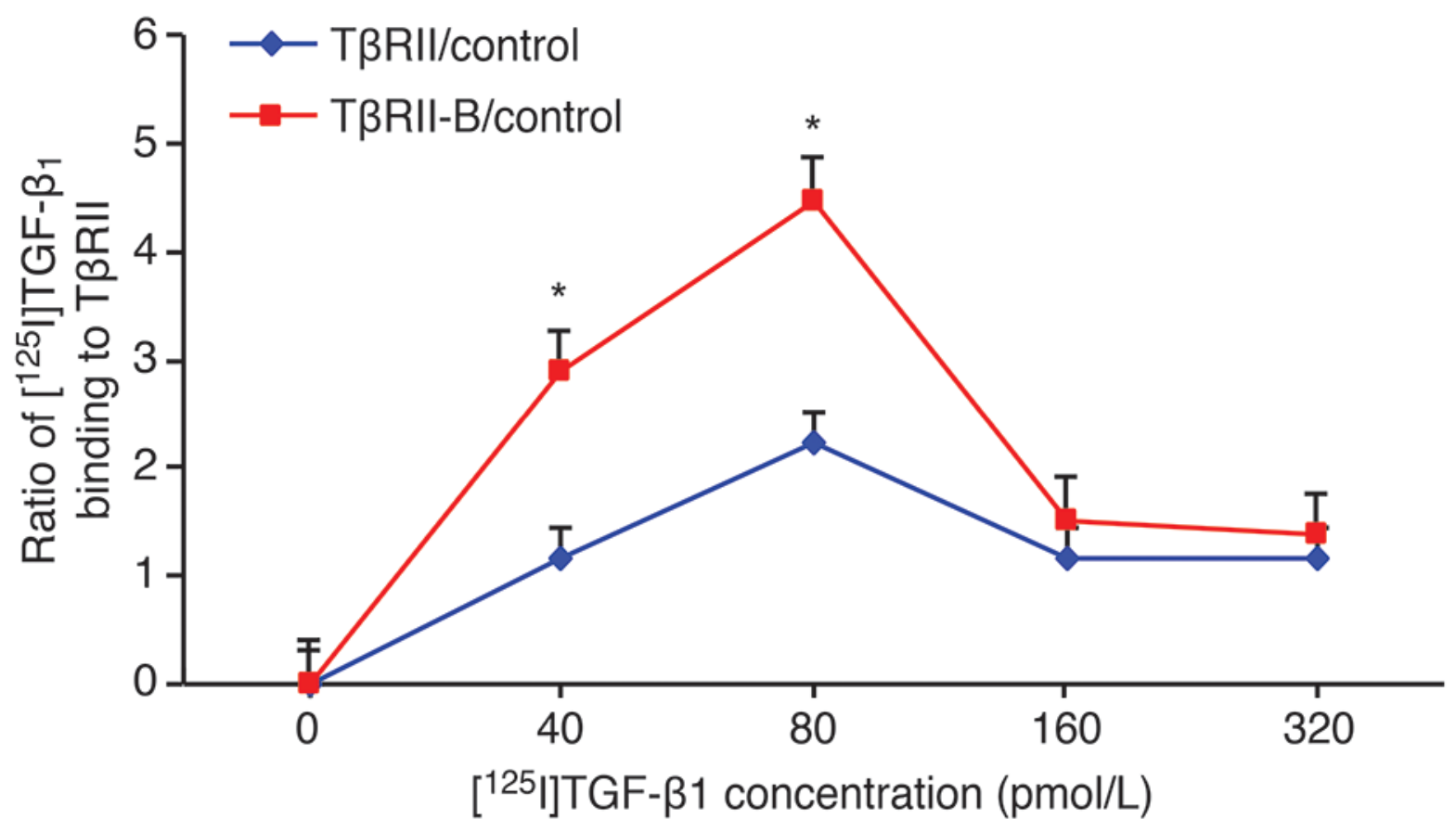

Figure 6: TGF- $\beta 1$ has a higher affinity for T $\beta$ RII-B than for T $\beta$ RII. Different concentrations of $\left[{ }^{125}\right.$ I]TGF- $\beta 1$ were incubated with K562 cells that stably expressed T $\beta$ RII or T $\beta$ RII-B and the ratio of [ $\left.{ }^{125} \mathrm{I}\right] \mathrm{TGF}-\beta 1$ binding calculated. K562 parental cells served as a control. The data are representative of two independent experiments. The data represent the mean $\pm \mathrm{SEM}$. $* \mathrm{P}<0.05$, two-tailed Student's $t$-test. 
Table 1: TßRII expression levels and clinical characteristics in AML patients

\begin{tabular}{|c|c|c|c|c|}
\hline \multirow[t]{2}{*}{ Patient characteristics } & \multicolumn{3}{|c|}{ No. of patients (\%) } & \multirow[b]{2}{*}{ P-value } \\
\hline & $\begin{array}{l}\text { AML patients } \\
\qquad(\mathrm{n}=138)\end{array}$ & $\begin{array}{c}\text { TßRII }{ }^{\text {low }} \\
(n=78)\end{array}$ & $\begin{array}{l}\text { TßRII }{ }^{\text {high }} \\
(n=60)\end{array}$ & \\
\hline \multicolumn{5}{|c|}{$\begin{array}{l}\text { Complete remission after two } \\
\text { cycles of therapy }\end{array}$} \\
\hline Yes & $78(56.5 \%)$ & $54(69.2 \%)$ & $24(40 \%)$ & $<0.01$ \\
\hline No & $60(43.5 \%)$ & $24(30.8 \%)$ & $36(60 \%)$ & \\
\hline \multicolumn{5}{|c|}{$\begin{array}{l}\text { White blood cell count }\left(\times 10^{6}\right. \\
\text { cells } / \mathrm{ml})\end{array}$} \\
\hline Median & 48.23 & 19.2 & 64.16 & $<0.05$ \\
\hline Range & $0.76-254.8$ & $0.76-153.9$ & $0.99-254.8$ & \\
\hline
\end{tabular}

T $\beta R I^{\text {low }}$ and T $\beta R I^{\text {high }}$ represent the $20 \%$ of patients with the lowest T $\beta$ RII mRNA levels and the $20 \%$ with the greatest expression (the relative mRNA level is the ratio of the experimental data to the internal control data). $\mathrm{P}<0.01$ and $\mathrm{P}<0.05$, $X^{2}$ analysis.
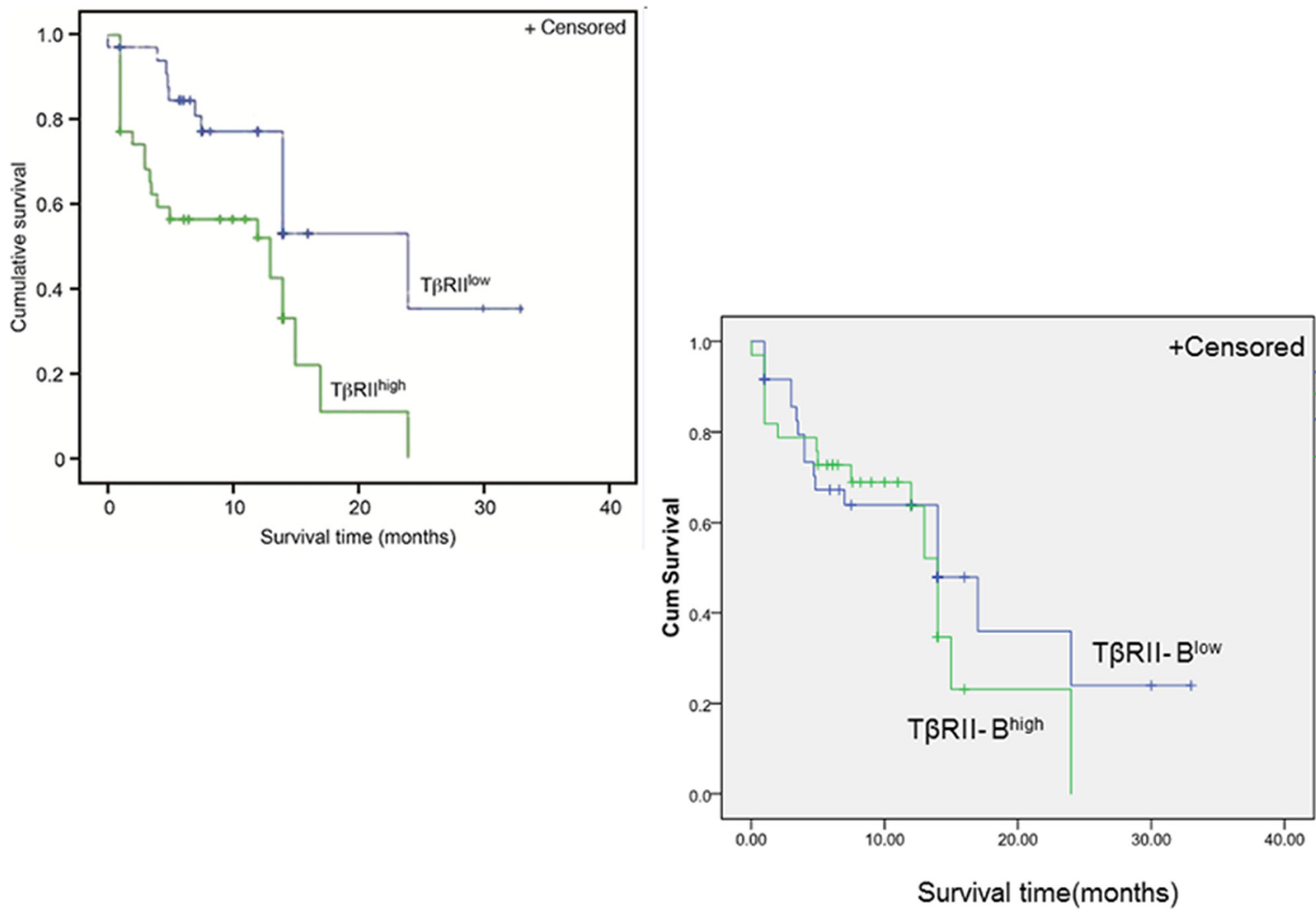

Figure 7: Higher T $\beta$ RII expression is correlated with a poor clinical prognosis in AML patients. Multivariate survival analysis of AML patients according to T $\beta$ RII and T $\beta$ RII-B expression. Kaplan-Meier survival curve. $\mathrm{n}=138$ patients. The overall survival rates of patients with high T $\beta$ RII expression were significantly lower than those of patients with low T $\beta$ RII expression $(34.3 \%$ vs. $61.8 \%$, $\mathrm{P}=0.005$ ). The overall survival rates of patients with high T $\beta$ RII-B expression did not significantly differ from those of patients with low T $\beta$ RII-B expression ( $45.5 \%$ vs. $50 \%, \mathrm{P}>0.05)$. 
C-terminus of T $\beta R I$ to form a TGF- $\beta 3$ :T $\beta$ RII:T $\beta R I$ tertiary complex. Disrupting the interaction between these two receptors could block complex formation and downstream Smad signaling. The $\mathrm{N}$-terminus of TRRII-B contains an insertion of 26 amino acids that replaces Val32, which corresponds to Val9 in the TßRII $\mathrm{N}$-terminus. Here, binding assays indicated that at low TGF- $\beta 1$ concentrations, the binding affinity of TGF- $\beta 1$ for K562/T $\beta$ RII-B cells was much stronger than for K562/T $\beta R I I$ cells. Thus, differences in binding of T $\beta R I I$ isoforms to TGF- $\beta 1$ may affect the interaction between T $\beta$ RII and T $\beta R I$ and activation of downstream signaling pathways. To confirm that the two T $\beta$ RII isoforms have different biological functions in vivo, we generated HL60 xenograft mouse models. We found that HL60/ T $\beta$ RII-B cells exhibited reduced tumorigenicity in nude mice compared to HL60/T $\beta$ RII cells.

Because differences in the expression and function of the two T $\beta$ RII isoforms have been documented in myeloid leukemia cells, we compared data on the clinical features and prognosis of 138 AML patients. AML patients with high T $\beta$ RII expression had elevated white blood cell counts, lower complete remission rates, and lower overall survival rates than AML patients with low T $\beta$ RII expression. Therefore, T $\beta$ RII might be a prognostic marker in AML.

One limitation of this study is that the TRRII receptor subunits are overexpressed on myeloid leukemia cells. These cells do not normally express the receptor and therefore might not be physiologically primed to respond to TGF- $\beta$. Another potential limitation is that leukemic cells form solid tumors rather than hematopoietic cancers in the xenograft model. However, we simply used these cell lines and mouse models to elucidate the effects of the different isoforms on cell proliferation. Further studies involving intravenous transplantation of leukemia cells with varying T $\beta$ RII expression should be performed to confirm our results. Additionally, the impact of targeting T $\beta$ RII in leukemic cells could be investigated to analyze the potential therapeutic efficacy.

In conclusion, we have demonstrated that T $\beta$ RII-B, but not T $\beta$ RII, has the capacity to induce cell cycle arrest, apoptosis, and differentiation. Higher TRRII expression is correlated with a worse prognosis in AML patients.

\section{MATERIALS AND METHODS}

\section{Patient population}

A total of 138 previously untreated AML patients were selected at Union Hospital, which is affiliated with Fujian Medical University. The characteristics of the patients are shown in Supplementary Table 6. Bone marrow samples from 10 healthy donors were used as controls.

\section{Cell lines and separation of mononuclear cells}

The K562 (ATCC No. CCL-243), HL60 (ATCC No. CCL-240), U937 (ATCC No. CRL-1593.2), KG1 (ATCC No. CCL-246), and HEL (ATCC No. TIB-180) cell lines were purchased from ATCC, and the NB4 cell line was purchased from the Institute of Cell Biology, Chinese Academy of Sciences. All cells were cultured in RPMI 1640 medium (Gibco/BRL) supplemented with $10 \%$ fetal bovine serum (FBS). Mononuclear cells were separated from $5 \mathrm{~mL}$ bone marrow samples using lymphocyte separation medium (specific gravity, $1.077 \mathrm{~g} /$ $\mathrm{mL}$ ) according to the manufacturer's instructions.

\section{Isolation of CD34+ cells from normal bone marrow}

Fluorescence activated cell sorting (FACS) was performed with a FACSAria I flow cytometer (Becton Dickinson) according to the manufacturer's protocol. $\mathrm{CD} 34+$ cells in the normal bone marrow cell fractions were sorted based on positive labeling with a FITCanti-human CD34 antibody. The data for 10,000 events were then analyzed using the FlowJo software. The cells were sorted into $5 \mathrm{~mL}$ tubes containing $2 \mathrm{~mL}$ DMEM supplemented with $10 \%$ FBS, and the FSC threshold was set to exclude cell debris. The viability of the isolated cells was assessed using the trypan blue exclusion method. After sorting, the cells were collected, centrifuged, and resuspended in $10 \mathrm{~mL}$ cold DMEM/FBS. The tubes were stored in the dark on ice until RNA extraction was performed.

\section{RNA extraction, RT-PCR, and real-time PCR}

Total RNA was extracted using TRIzol reagent (Invitrogen). The cDNA was synthesized using a reverse transcription kit (Toyobo). Isoform (T $\beta$ RII and T $\beta$ RII-B) expression was detected by RT-PCR. Specific primer sets were designed to detect different T $\beta$ RII isoforms based on the presence of exon 2. The sequences of the primers are shown in Supplementary Table 2. The product length of T $\beta$ RII-B was $234 \mathrm{bp}$ and the product length of T $\beta$ RII was 159 bp. Quantitative real-time PCR analysis of T $\beta$ RII isoform (T $\beta$ RII and T $\beta$ RII-B) expression was performed using a model 7500 thermocycler (ABI). The primer and probe sequences are shown in Supplementary Table 7, and TaqMan probes (ABI) were used in all experiments. Different dilutions of the target genes as well as the internal control gene $(A B L 1)$ were included in order to calculate a standard curve. Quantitative analysis of mRNAs involved in cell cycle control, apoptosis, and differentiation was performed using a SYBR Green Realtime PCR kit (Toyobo). All experiments were performed according to the manufacturer's instructions. The primer sequences are shown in Supplementary Table 8. The 
relative transcript levels were calculated using the $2^{-\Delta \Delta \mathrm{Ct}}$ method, with all data normalized to the level of $\beta$-actin.

\section{Generation of stable cell lines}

K562 and HL60 cells were cultured in RPMI 1640 medium (Gibco/BRL) supplemented with 10\% FBS. The pEFIRES-T $\beta$ RII and pEFIRES-T $\beta$ RII-B vectors were constructed by inserting the human TRRII and T $\beta R I I-B$ cDNA open reading frames, respectively, into a pEFIRES-Neo eukaryotic expression plasmid (gift from Ian G. Young, John Curtin School of Medical Research, Australian National University, Canberra, AU) and were confirmed by sequencing (BigDye Terminator 3.0, ABI). We transfected pEFIRES-T $\beta$ RII and pEFIRES-T $\beta$ RII-B into K562 and HL60 cells using the Lipofectin ${ }^{\mathrm{TM}}$ reagent (Life Technologies). Cells were selected with hygromycin $(100 \mu \mathrm{g} / \mathrm{mL})$. Cell lines stably expressing TRRII or T $\beta$ RII-B were screened using quantitative RT-PCR and Western blotting confirm T $\beta$ RII expression.

\section{Lentiviral vector construction and infection}

NB4 cells were cultured in RPMI 1640 medium (Gibco/BRL) supplemented with 10\% FBS. Lentiviral vectors designed to express human T $\beta R I I$ siRNA or T $\beta R I I$ splice variants $(\mathrm{Mu})$, and negative control vectors were constructed with the aid of Shanghai GeneChem. The siRNA sequences targeting T $\beta$ RII were designed to silence both endogenous T $\beta$ RII splice variants using an Invitrogen Neon Transfection System (MPK5000). A doublestranded oligonucleotide encoding the shRNA sequence, a mismatched siRNA mutant, and sequences encoding the two T $\beta$ RII splice variants $(\mathrm{Mu})$ tagged with green fluorescent protein (GFP) were annealed and inserted into the pGC-LV expression vector (Invitrogen). The siRNA and T $\beta R I I$ splice variant $(\mathrm{Mu})$ expression vectors (pGC-LV), and the packaging vectors (pHelper 1.0 and pHelper 2.0; Invitrogen) were cotransfected into 293FT cells using Lipofectamine 2000 (Invitrogen). The culture supernatants were collected, concentrated, and stored at $-70^{\circ} \mathrm{C}$. Enhanced GFP (eGFP) was expressed in all lentiviral vectors to measure viral titer and infection efficiency. The lentiviral vectors were introduced into NB4 cells in the presence of polybrene $(10 \mathrm{mg} / \mathrm{mL})$, with an MOI of 5-20.

\section{Cell proliferation assays}

MTT assays were performed using an MTT Cell Proliferation Assay Kit (Amresco) according to the manufacturer's instructions. Formazan absorbance was measured at $490 \mathrm{~nm}$ on an ELX800 microplate reader (BioTek). The following formula was used to quantify the effect on cell proliferation: cell proliferation inhibition rate $=(1-$ OD value of experimental group $/ \mathrm{OD}$ of the control group) $\times 100 \%$.

\section{Flow cytometry}

Cell cycle analysis was performed using a cell cycle assay kit (Promega) according to the manufacturer's instructions. Flow cytometry cell cycle analysis was performed using a FACSAria I flow cytometer. The ModFit LT software was used to quantify DNA ploidy. Apoptosis was quantified using an Annexin V-FITC Apoptosis Detection Kit (Promega) according to the manufacturer's instructions. The data were analyzed using the FlowJo software (version 7.6.1; TreeStar). The cell surface differentiation antigen $\mathrm{CD} 11 \mathrm{~b}$ was detected by FACS. Briefly, $1 \times 10^{6}$ cells were stained with FITC-antihuman $\mathrm{CD} 11 \mathrm{~b}$ for $20 \mathrm{~min}$ at room temperature. The cells were then washed and resuspended in FACS buffer. The cells were analyzed immediately after immunostaining using the FACSAria I and FlowJo Version 7.6.1 software.

\section{Western blotting}

Total cell lysates were harvested and boiled in sample buffer. Equal amounts of protein lysate were resolved by SDS-PAGE and transferred onto polyvinylidene fluoride membranes (Millipore). The following primary antibodies were used in our analysis: anti-T $\beta$ RII, anti- $\beta$-actin (Santa Cruz Biotechnology, Inc.), anti-p21CIP/WAF1, and anti-c-Myc (Cell Signaling Technology). Proteins were visualized by enhanced chemiluminescence (Amersham Biosciences).

\section{Phospho-protein profiling with a phospho- antibody array}

Phospho-protein profiling was performed by the Biochip National Engineering Research Center of Shanghai, China. The TGF- $\beta 1 /$ Smad Pathway Phosphorylation Antibody Array was designed and manufactured by Full Moon Biosystems, Inc. Total protein labeling, chip sealing, hybridization, and detection were performed according to the manufacturer's instructions. The microarrays were scanned with a GenePix 4000B array scanner and the mean values, CV values, and phosphorylation ratios calculated. The array contained 176 different antibodies, 74 of which targeted specific phosphorylation sites. For each antibody, we calculated the phosphorylation ratio using the following formula (phosphorylated and matching unphosphorylated values are denoted by "phospho" and "unphospho", respectively, in both the control and the experimental data).

$$
\text { phosphorylation ratio }=\frac{\text { phospho }(\text { experiment })}{\text { unphospho (experiment) }} / \frac{\text { phospho }(\text { control })}{\text { unphospho }(\text { control })}
$$




\section{$\left[{ }^{125}\right.$ I]TGF- $\beta 1$ binding assays}

The $\left[{ }^{125}\right.$ I]TGF- $\beta 1$ was obtained from Beijing Atomic Hi-Tech Technology Co., Ltd., reconstituted in $100 \mathrm{~mL} 4 \mathrm{mM} \mathrm{HCl}$ containing $2 \mathrm{mg} / \mathrm{mL}$ BSA and diluted with binding buffer to generate a $100 \mathrm{pM}$ stock solution. Aliquots were stored at $-80^{\circ} \mathrm{C}$ until use. The $\left[{ }^{125} \mathrm{I}\right] \mathrm{TGF}-\beta 1$ binding assays were performed as previously described [30]. To prepare cultures for binding studies, cells were seeded into six-well dishes and grown for $24 \mathrm{~h}$. The medium was removed and the cells washed with $1 \mathrm{~mL}$ binding buffer and allowed to equilibrate at $4^{\circ} \mathrm{C}$. After $30 \mathrm{~min}$, the plates were transferred to ice and the binding buffer aspirated. Icecold binding buffer and $\left[{ }^{125} \mathrm{I}\right] \mathrm{TGF}-\beta 1$ were added to different concentrations of $\left[{ }^{125}\right.$ I]TGF- $\beta 1$ (range 5-320 $\mathrm{pM}$ ). The final volume was $2 \mathrm{~mL}$. The cells were then incubated at $4^{\circ} \mathrm{C}$ for $3.5 \mathrm{~h}$ on a platform that oscillated at $120 \mathrm{rpm}$. A 50 -fold excess of unlabeled TGF- $\beta 1$ was added immediately before the incubation with $\left[{ }^{125} \mathrm{I}\right] \mathrm{TGF}-\beta 1$ in order to determine the amount of $\left[{ }^{125} \mathrm{I}\right]$ TGF- $\beta 1$ that bound non-specifically to the surface of cells. In parallel, binding buffer without $\left[{ }^{125} \mathrm{I}\right] \mathrm{TGF}-\beta 1$ was added to six-well plates for cell counting using a Neubauer counting chamber. Based on the work by Kang et al. [31], the following ratio of $\left.{ }^{125}{ }^{125}\right]$ TGF- $\beta 1$ binding to T $\beta R I I$ was calculated:

$$
\text { TGF- } 31 \text { binding ratio }=\frac{\text { binding }(\text { experiment })}{\text { binding }(\text { control })}
$$

\section{In vivo assays of tumorigenesis}

Female BALB/c nude mice (4-6 weeks old) were obtained from the Shanghai Laboratory Animal Breeding Center at the Chinese Academy of Medical Sciences. HL60/TßRII or HL60/T $\beta$ RII-B cells $\left(1 \times 10^{7}\right)$ were subcutaneously inoculated into the right flanks of the mice and tumor growth measured with a caliper. Tumors were allowed to grow until they became palpable (day 22). The mice were then sacrificed and the tumors removed and weighed. The tumor volume $\left(\mathrm{cm}^{3}\right)$ was calculated according to Bhola et al ${ }^{32}$ using the following formula: volume $=$ length $/ 2 \times$ width $^{2}$.

\section{Statistical analysis}

All experiments were repeated with samples from at least two different cell preparations. All results are expressed as the mean \pm standard error of the mean (SEM). Statistical significance was assessed using twotailed Student's $t$-tests. The association between T $\beta$ RII-B expression and overall survival was analyzed using the Kaplan-Meier method, and statistical significance was calculated based on log-rank tests. In all cases, $\mathrm{P}<0.05$ was considered significant.

\section{Study approval}

All mice were maintained under pathogenfree conditions at Fujian Medical University, and all experiments were performed in accordance with the protocols of the Institutional Animal Care and Use Committee. Normal and clinical samples were collected from AML patients according to a protocol approved by the Fujian Medical University Ethics Committee. Written informed consent was also obtained.

\section{CONFLICTS OF INTERST}

The authors declare that there are no conflicts of interests.

\section{FUNDING}

This project was supported by the Chinese National Key Program of Clinical Science (Hematology), the Fujian Provincial Key Laboratory on Hematology Program (Grant No. 2009J1004), the National Natural Science Foundation of China (Grant No. 81270571), and the Key Sci-Tech Special Project of Fujian (Grant No. 09ZD001).

\section{REFERENCES}

1. Fortunel NO, Hatzfeld A, Hatzfeld JA. Transforming growth factor-beta: pleiotropic role in the regulation of hematopoiesis. Blood. 2000; 96:2022-2036.

2. Ruscetti FW, Akel S, Bartelmez SH. Autocrine transforming growth factor-beta regulation of hematopoiesis: many outcomes that depend on the context. Oncogene. 2005; 24:5751-5763.

3. Shi Y, Massagué J. Mechanisms of TGF-beta signaling from cell membrane to the nucleus. Cell. 2003; 113:685-700.

4. Taylor IW, Wrana JL. SnapShot: the TGF-beta pathway interactome. Cell. 2008; 133:378.e1.

5. Gong J, Ammanamanchi S, Ko TC, Brattain MG. Transforming growth factor beta 1 increases the stability of p21/WAF1/CIP1 protein and inhibits CDK2 kinase activity in human colon carcinoma FET cells. Cancer Res. 2003; 63:3340-3346.

6. Gerber JM, Gucwa JL, Esopi D, Gurel M, Haffner MC, Vala M, Nelson WG, Jones RJ, Yegnasubramanian S. Genome-wide comparison of the transcriptomes of highly enriched normal and chronic myeloid leukemia stem and progenitor cell populations. Oncotarget. 2013; 4:715-728. doi: 10.18632/oncotarget.990.

7. Yang S, Cho YJ, Jin L, Yuan G, Datta A, Buckhaults P, Datta PK. An epigenetic auto-feedback loop regulates TGF- $\beta$ type II receptor expression and function in NSCLC. Oncotarget. 2015; 6:33237-52. doi: 10.18632/oncotarget.4893.

8. Cheng H, Wang S, Feng R. STIM1 plays an important role in TGF- $\beta$-induced suppression of breast cancer cell 
proliferation. Oncotarget. 2016, 7:16866-16878. doi: 10.18632/oncotarget.7619.

9. Liu C, Billadeau DD, Abdelhakim H, Leof E, Kaibuchi K, Bernabeu C, et al. IQGAP1 suppresses T $\beta$ RII-mediated myofibroblastic activation and metastatic growth in liver. J Clin Invest. 2013; 123:1138-1156.

10. Kim S, Letterio J. Transforming growth factor-beta signaling in normal and malignant hematopoiesis. Leukemia. 2003; 17:1731-1737.

11. Lin H, Bergmann S, Pandolfi PP. Deregulated TGF- $\beta$ signaling in leukemogenesis. Oncogene. 2005; 24:5693-5700.

12. Imai Y, Kurokawa M, Izutsu K, Hangaishi A, Maki K, Ogawa S,et al. Mutations of the Smad4 gene in acute myelogeneous leukemia and their functional implications in leukemogenesis. Oncogene. 2001; 20:88-96.

13. Chen Y, Lu L, Wang L. Study on gene expression of TGF beta 1 and its receptor in leukemia cells and the serum TGF beta 1 level in the patients with acute leukemia. Zhonghua Xue Ye Xue Za Zhi. 1998; 19:576-580.

14. Wu Y, Chen P, Huang H, Huang M, Chen Y. Reduction of transforming growth factor- $\beta 1$ expression in leukemia and its possible role in leukemia development. Leuk Lymphoma. 2012; 53:145-151.

15. Le Bousse-Kerdiles MC, Chevillard S, Charpentier A, Romquin N, Clay D, Smadja-Joffe F, et al. Differential expression of transforming growth factor-beta, basic fibroblast growth factor, and their receptors in CD34+ hematopoietic progenitor cells from patients with myelofibrosis and myeloid metaplasia. Blood. 1996; 88:4534-4546.

16. Hirai R, Fujita T. A human transforming growth factor-beta type II receptor that contains an insertion in the extracellular domain. Exp Cell Res.1996; 223:135-141.

17. Rotzer D, Roth M, Lutz M, Lindemann D, Sebald W, Knaus P. Type III TGF-beta receptor-independent signalling of TGF-beta2 via TbetaRII-B, an alternatively spliced TGFbeta type II receptor. EMBO J. 2001; 20:480-490.

18. Del Re E, Babitt JL, Pirani A, Schneyer AL, Lin HY. In the absence of type III receptor, the transforming growth factor (TGF)-beta type II-B receptor requires the type I receptor to bind TGF-beta2. J Biol Chem. 2004; 279:22765-22772.

19. Parker WL, Finnson KW, Soe-Lin H, Knaus P, Philip A. Expression and function of TbetaRII-B, a variant of the type II TGF-beta receptor, in human chondrocytes. Osteoarthritis Cartilage. 2007; 15:442-453.

20. Chen P, Chen YZ, Wu Y, Huang HF, Li NN. Identification of the isoform in type II receptor of transforming growth factor-beta in patients with acute leukemia and its clinical significance. Zhongguo Shi Yan Xue Ye Xue Za Zhi. 2006; $14: 221-224$
21. Pachernik J, Soucek K, Hampl A, Hofmanová J, Kozubík A. Transforming growth factor-betal induces junB mRNA accumulation, G1-phase arrest, and pRb dephosphorylation in human leukemia HL-60 cells. Folia Biol (Praha). 2001; 47:32-35.

22. Huang MJ, Wu LD, Chen YZ. TGF- $\beta 1$ involved in all transretinoic acid-stimulated differentiation of HL60 cells. Chin J Biochem Mol Biol. 2008; 24:444-451.

23. Matsunawa M, Ishii $\mathrm{Y}$, Kasukabe $\mathrm{T}$, Tomoyasu $\mathrm{S}$, Ota $\mathrm{H}$, Honma Y. Cotylenin A-induced differentiation is independent of the transforming growth factor-beta signaling system in human myeloid leukemia HL-60 cells. Leuk Lymphoma. 2006; 47:733-740.

24. Cao Z, Flanders KC, Bertolette D. Levels of phosphoSmad2/3 are sensors of the interplay between effects of TGF- $\beta 1$ and retinoic acid on monocytic and granulocytic differentiation of HL-60 cells. Blood. 2003; 101:498-507.

25. Chen $\mathrm{YZ}, \mathrm{Wu} \mathrm{Y}$, Huang MJ. Effect of endogenous TGF- $\beta 1$ and TNF- $\alpha$ on the $\mathrm{AS}_{2} \mathrm{O}_{3}$ inducing apoptosis of HL-60 cells. Chin J Hematol. 2003; 24:231-234.

26. Yu JX, Meng YL, Li Y. Levels of P27Kip1 expression and apoptosis in HL-60 cells after treatment with TGF- 31 and/ or arsenic trioxide. Zhongguo Shi Yan Xue Ye Xue Za Zhi. 2010; 18:893-897.

27. Ohishi K, Katayama N, Itoh R, Mahmud N, Miwa H, Kita K et al. Accelerated cell-cycling of hematopoietic progenitors by the fit3 ligand that is modulated by transforming growth factor- $\beta 1$. Blood. 1996; 87:1718-1727.

28. Radaev S, Zou Z, Huang T, Lafer EM, Hinck AP, Sun PD. Ternary complex of transforming growth factor-beta 1 reveals isoform-specific ligand recognition and receptor recruitment in the superfamily. J Biol Chem. 2010; 285:14806-14814.

29. Groppe J, Hinck CS, Samavarchi-Tehrani P. Cooperative assembly of TGF- $\beta$ superfamily signaling complexes is mediated by two disparate mechanisms and distinct modes of receptor binding. Mol Cell. 2008; 29:157-168.

30. Tucker RF, Branum EL, Shipley GD, Ryan RJ, Moses HL. Specific binding to cultured cells of 125I-labeled type $\beta$ transforming growth factor from human platelets. Proc Natl Acad Sci USA. 1984; 81:6757-6761.

31. Kang S, Elf S, Lythgoe K, Hitosugi T, Taunton J, Zhou $\mathrm{W}$, et al.p90 ribosomal S6 kinase 2 promotes invasion and metastasis of human head and neck squamous cell carcinoma cells. J Clin Invest. 2010; 120:1165-1177.

32. Bhola NE, Balko JM, Dugger TC, Kuba MG, Sánchez V, Sanders M, et al. TGF- $\beta$ inhibition enhances chemotherapy action against triple-negative breast cancer. J Clin Invest. 2013; 123:1348-1358. 